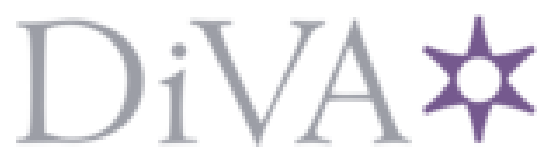

http://www.diva-portal.org

This is the published version of a paper presented at EURODYN 2O2O, XI International Conference on Structural Dynamics, Athens, Greece, 22-24 June 2020.

Citation for the original published paper:

Abrahamsen, R., Bjertnaes, M A., Bouillot, J., Brank, B., Cabaton, L. et al. (2020)

Dynamic Response of Tall Timber Buildings Under Service Load: The DynaTTB

Research Program

In: M. Papadrakakis, M. Fragiadakis, C. Papadimitriou (ed.), EURODYN 202O, XI international conferece on structural dynamics: Proceedings, Volym II (pp. 4900-4910). National Technical University of Athens

N.B. When citing this work, cite the original published paper.

Permanent link to this version:

http://urn.kb.se/resolve?urn=urn:nbn:se:lnu:diva-99080 


\title{
DYNAMIC RESPONSE OF TALL TIMBER BUILDINGS UNDER SERVICE LOAD - THE DYNATTB RESEARCH PROGRAM
}

\author{
Rune Abrahamsen ${ }^{1}$, Magne A Bjertnæs ${ }^{2}$, Jacques Bouillot ${ }^{3}$, Bostjan Brank ${ }^{4}$, Lionel \\ Cabaton $^{5}$, Roberto Crocetti ${ }^{6}$, Olivier Flamand ${ }^{7}$, Fabien Garains ${ }^{3}$, Igor Gavric ${ }^{8}$, Olivier \\ Germain $^{9}$, Ludwig Hahusseau ${ }^{3}$, Stephane Hameury ${ }^{7}$, Marie Johansson ${ }^{10}$, Thomas Jo- \\ hansson $^{6}$, Wai Kei Ao ${ }^{11}$, Blaž Kurent ${ }^{4}$, Pierre Landel ${ }^{10}$, Andreas Linderholt ${ }^{12}$, Kjell \\ Malo $^{13}$, Manuel Manthey ${ }^{7}$, Petter Nåvik ${ }^{2}$, Alex Pavic ${ }^{11}$, Fernando Perez ${ }^{14}$, Anders \\ Rönnquist $^{13}$, Haris Stamatopoulos ${ }^{13}$, Iztok Sustersic ${ }^{8}$, Salue Tulebekova ${ }^{13}$
}

\author{
Corresponding Author: Olivier Flamand \\ CSTB \\ olivier.flamand@cstb.fr
}

Other addresses in the footnote below.

Keywords: Timber building, wind load, discomfort, modelling, damping, full scale.

\begin{abstract}
Wind-induced dynamic excitation is becoming a governing design action determining size and shape of modern Tall Timber Buildings (TTBs). The wind actions generate dynamic loading, causing discomfort or annoyance for occupants due to the perceived horizontal sway - i.e. vibration serviceability failure. Although some TTBs have been instrumented and measured to estimate their key dynamic properties (natural frequencies and damping), no systematic evaluation of dynamic performance pertinent to wind loading has been performed for the new and evolving construction technology used in TTBs. The DynaTTB project, funded by the Forest Value research program, mixes on site measurements on existing buildings excited by heavy shakers, for identification of the structural system, with laboratory identification of building elements mechanical features coupled with numerical modelling of timber structures. The goal is to identify and quantify the causes of vibration energy dissipation in modern TTBs and provide key elements to FE modelers.
\end{abstract}

The first building, from a list of 8, was modelled and tested at full scale in December 2019. Some results are presented in this paper. Four other buildings will be modelled and tested in spring 2021.

\footnotetext{
${ }_{1}^{1}$ Moelven Limtre, rune.abrahamsen@moelven.no, ${ }^{2}$ Sweco, magne.bjertnaes@sweco.no, petter.navik@sweco.no, ${ }^{3}$ Eiffage, jacques.bouillot@eiffage.com, ludwig.hahusseau@eiffage.com, ${ }^{4}$ Uni Ljubjana, Bostjan.Brank@ikpir.fgg.uni-lj.si, bkurent@fgg.uni-lj.si, ${ }^{5}$ Arbonis, lcabaton@arbonis.com, fgarains@arbonis.com, ${ }^{6}$ Moelven SE, crocetti@kth.se, thomas.johansson@moelven.se, ${ }^{7} \mathrm{CSTB}$, olivier.flamand@cstb.fr, stephane.hameury@cstb.fr, manuel.manthey@cstb.fr, ${ }^{8}$ InnoRenew CoE, igor.gavric@innorenew.eu, iztok.sustersic@innorenew.eu, ${ }^{9}$ Galeo,o.germain@galeo.fr, ${ }^{10}$ RISE, marie.johansson@ri.se, pierre.landel@ri.se, ${ }^{11}$ Uni Exeter, wka203@exeter.ac.uk, A.Pavic@exeter.ac.uk ${ }^{12}$ LNU, andreas.linderholt@lnu.se, ${ }^{13}$ NTNU, kjell.malo@ntnu.no, anders.ronnquist@ntnu.no, haris.stamatopoulos@ntnu.no,saule.tulebekova@ntnu.no ${ }^{14}$ Smith\&Wallwork, fernando.perez@smithandwallwork.com
} 


\section{INTRODUCTION}

\subsection{Background}

Due to population expansion and concentration in urban regions, housing shortage is an increasing global issue, necessitating the efficient use of space in urban areas. One solution is an increased supply of tall buildings to optimize the best use of limited space. This has sustainability impacts surrounding the choice of materials and carbon footprint ramifications. Using more wood-based products in building construction, as a renewable raw material, could assist in the transition of society towards a circular based bio-economy, moving away from a dependence on fossil fuels and extractive materials, whilst helping meet the commitments contained within the UN Sustainable Development Goals. The use of tall buildings with timber structures would be an opportunity to create value and impact by encouraging the increased use of forestbased replenishable products. Tall Timber Buildings could provide cost effective, environmentally sustainable developments, maximising the limited space available in urban regions.

Tall Timber Buildings ( $>10$ storeys) is still a very new concept, some examples are:

- Murray Grove (London, UK (2009)) - 9 storeys,

- Forté (Melbourne, Australia (2012)) - 10 storeys,

- Treet (Bergen, Norway (2015)) - 14 storeys,

- Brook Commons (Vancouver, Canada (2017)) - 18 storeys,

- Origine (Quebec City, Canada (2018)) - 13 storeys and

- Mjøstårnet (Brumunddal, Norway (2019)) - 18 storeys.

The load-bearing system of these buildings are very different giving the buildings different properties. Building tall means several new challenges such as higher loads vertically and horizontally, earthquake loads, fire safety and increased needs regarding technical systems as some examples. One aspect that is of special interest is the dynamic behavior related to wind-loads that leads to a need to limit acceleration levels at the top of buildings. This is a factor that has shown to govern the design of the stabilization system of tall timber buildings from a height of 12-14 storeys and above, see [1] for example. The understanding of the wind-induced dynamic behaviour of Tall Timber Buildings (TTBs) and their components is till poor and results in a lack of confidence by designers in the use of timber as a construction material. A lack of reliable data for modelling is one of the main barriers in the further development of TTBs and wider utilisation of timber within construction.

This lack of reliable data regarding modelling wind-induced vibrations for tall timber buildings was the motivation for starting the ForestValue project "DynaTTB - Dynamic Response of Tall Timber Buildings under Service Loads". The project will be performed by partners from academia, research institutes and companies ${ }^{2}$ from five different countries in Europe during 2019-2022. The research hypothesis for this project is that it is possible to create computational models for Tall Timber Buildings, based on system identification and calibration of advanced Finite Element (FE) models. This will be underpinned by data from full-scale tests of a number of representative mid-to-high rise timber buildings in Norway, Sweden, France, Slovenia and the UK. The project plan will utilize unique horizontal electro-dynamic sliding shakers from the University of Exeter (UK) and CSTB (France) to perform vibrational tests and use the data

\footnotetext{
${ }^{2}$ RISE Research Institutes of Sweden, NTNU Norwegian University of Science and Technology, University of Exeter, University of Ljubljana, InnoRenew Renewable Materials and Healthy Environments Research and Innovation Centre of Excellence (InnoRenew CoE), CSTB Centre Scientifique et Technique du Bâtiment, Linnaeus University, Moelven Töreboda AB, Moelven Limtre AS, SWECO Norge AS avd Lillehammer, Smith and Wallwork Engineers Ltd, Galeo, Eiffage Immobilier Sud Ouest, Arbonis.
} 
to estimate Frequency Response Functions (FRFs) for a number of TTBs with different building systems.

The overall objective of the project is to experimentally identify a number of full-scale TTB structures within Europe and, based on these results, develop representative FE-models to predict the vibration response of TTBs exposed to wind-induced dynamic loading.

This paper will present the structure of the project and the first preliminary results from the first two tested buildings.

\subsection{State-of-the-art}

There are several all timber building systems that can be used for the stabilizing system in TTBs. In principle these systems can be made up of one-dimensional elements in the form of beams and columns, mostly made of glulam, or two-dimensional elements such as cross laminated timber (CLT) or laminated veneer lumber (LVL). The one-dimensional elements can be used in moment-resisting frames or as trusses while the two-dimensional elements are used as shear walls to stabilize the buildings, see Figure 1. It is also possible to use hybrid structures with parts of the building system in steel or concrete to help support the building against especially horizontal loads. CLT elements are typically connected using shear or tension angular steel brackets and self-tapping screws [2]. The glulam members are typically jointed using dowelled connections with slotted-in steel plates - a jointing technique successfully applied in largespan timber bridges and sport arenas.
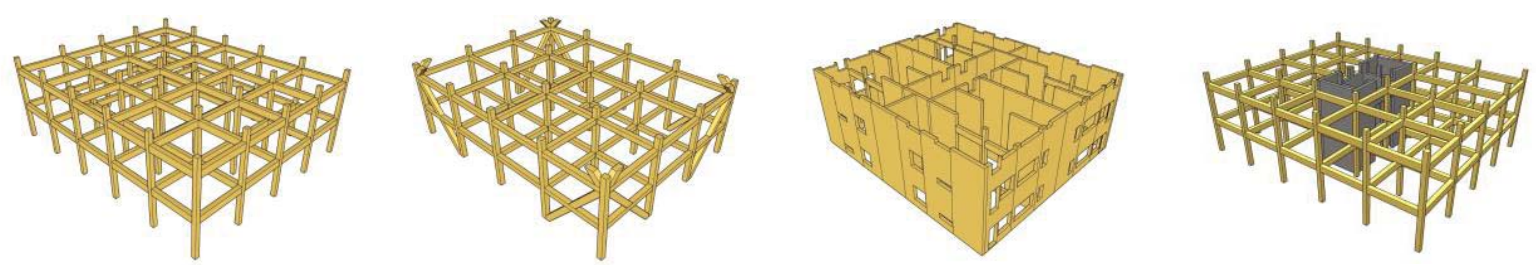

(c) Marie Johan sson

Figure 1: Principal buildings systems for Tall Timber Buildings, a) moment-resisting frames, b) truss-systems, c) shear wall systems and d) hybrid system combining timber with other materials.

TTBs have, in principle, sufficient strength capacity to resist lateral loads (e.g. wind, earthquake) for the ultimate limit state. However, instead the vibration serviceability limit state (SLS) governs the design, leading to the need to restrict wind-induced sway vibrations to within certain limits $[4,5]$. The lowest natural frequencies, dependent on mass and stiffness, of the TTB sway motion is in the same frequency range as the wind spectra. The sway is, however, also largely dependent on the damping of the structure. Timber is a light material with only moderate stiffness and hence the fulfilment of the vibration SLS criteria, due to wind, results in restrictions to the total building height $[6,7]$.

The amount of sway/acceleration depends on the mass and stiffness distribution of TTB structures and the ability to dissipate vibrational energy from the structural system. Currently, the knowledge on structural stiffness and damping in TTBs is limited, particularly regarding the effects of different types of connections used in the load-carrying systems. These connections are crucial generators of stiffness and damping, yet little is known as to their impact on TTB structures. Current modal damping values used in the design of TTBs are based on guess work, with minimal underpinning rational or scientific basis. 
Two major contributors to damping are: material damping and structural damping. Material damping arises from the internal friction within the material of a timber element, whilst structural damping is due to friction and energy dissipation in the connections. Non-structural elements and their connections are also assumed to contribute to the total damping. Timber structures are lightly damped systems and, therefore, due to the nature of resonant response calculations, a small change in the damping ratio can lead to significant changes in the vibration response and overall serviceability performance.

Although some TTBs have been instrumented and measured to estimate their key dynamical properties (natural frequencies, mode shapes and damping) [3], no systematic evaluation of dynamic performance pertinent to wind loading, has been performed for the innovative and evolving TTB construction technology. Knowing that the wind response calculations are highly sensitive to the damping values and natural frequencies, indicating that small variations in these uncertain modelling parameters may yield vastly different responses on either side of the acceptable vibration response values.

Full-scale tests on TTBs has been done using Operational Modal Analysis (OMA), also expressed as Ambient Vibration Testing (AVT), where the dynamic response is measured without knowledge of the load, [3, 8] for example). This technique gives relatively good results for natural frequencies and mode shapes but offers considerably less reliable values for damping. Using Forced Vibration Testing (FVT) gives the possibility of controlling the load level and thereby establishing Frequency Response Functions (FRFs) [9]. Using FVT gives the possibility of measuring over a range of frequencies and will result in better understanding of the dynamic response of TTBs as a function of excitation frequency, which is important for stochastic wind loading containing multiple frequencies. The FRFs also give a better base for model calibration of the FE-models of TTBs. The partners at University of Exeter and CSTB have unique equipment enabling measurements of dynamical properties of other types of large civil engineering structures, bridges and floors $[10,11]$ which will be used for TTBs in this project to provide excellent opportunities to establish unique and vital data.

FE models of full-scale TTBs have numerous uncertainties, for example, whereabouts stiffness and damping occur. Improved knowledge of the dynamic behaviour of TTBs can be developed through dynamic tests on full-scale building structures (in-situ), but these are time consuming and costly. The goal of this project is to limit the required number of tests and develop simulation tools such as reliable FE models.

\section{PROJECT PLAN}

The main objective of the project is to identify experimentally a number of full-scale TTB structures (existing or currently being built) and, based on these, develop representative FEmodels for predicting the vibration response of TTBs exposed to dynamic loading due to wind. Figure 2 includes eight TTBs (plus a timber bridge) that have been identified as potential candidates. In most cases the companies designing and building the structures are involved in the project as industry partners making drawings and calculation models available. Table 1 gives some data for the buildings such as height, width and depth as well as their main building system. 


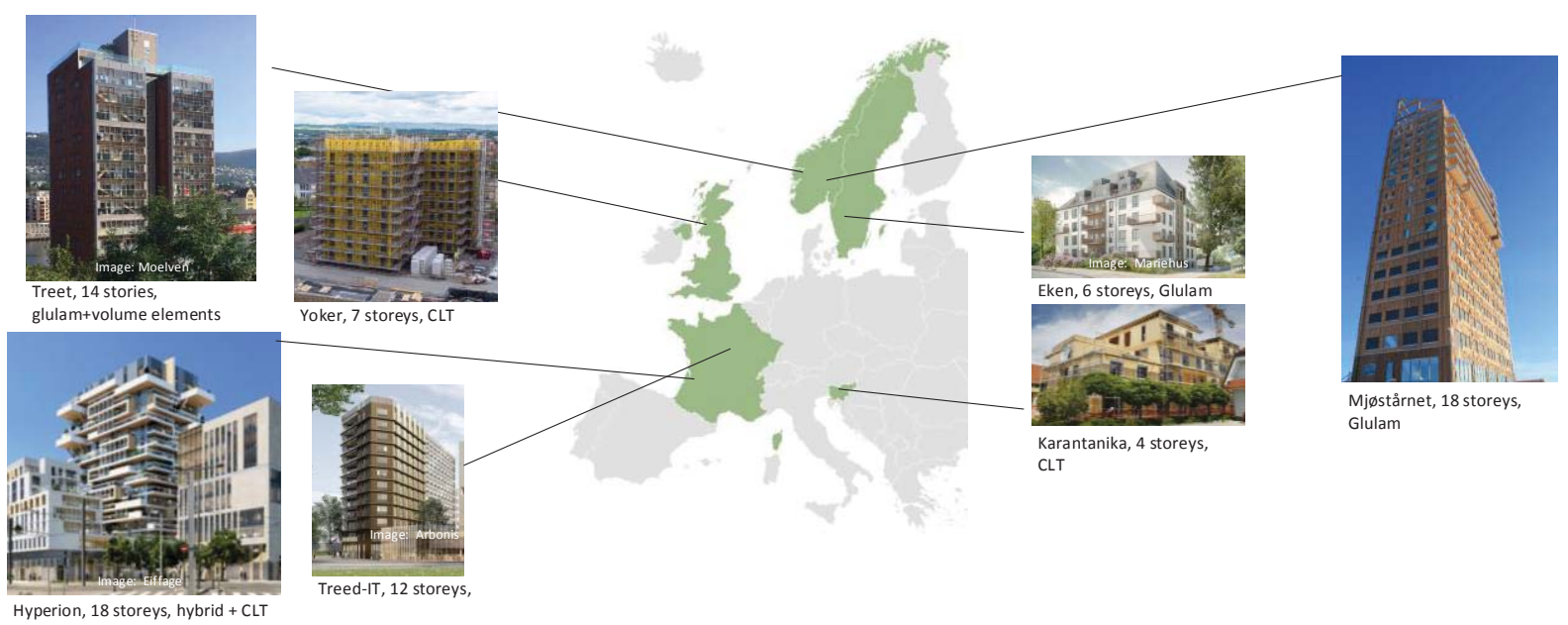

Figure 2: Map of Europe with the buildings that will be measured.

\begin{tabular}{|c|c|c|c|c|c|c|}
\hline $\begin{array}{l}\text { Building } \\
\text { name }\end{array}$ & Country & $\begin{array}{c}\text { Building } \\
\text { height }\end{array}$ & $\begin{array}{l}\text { Building } \\
\text { width }\end{array}$ & $\begin{array}{c}\text { Building } \\
\text { depth }\end{array}$ & $\begin{array}{c}\text { Load-bearing } \\
\text { system }\end{array}$ & $\begin{array}{l}\text { Stabilising ele- } \\
\text { ments }\end{array}$ \\
\hline Mjøstårnet & Norway & 85.4 & 36.8 & 16.3 & Glulam & Trusses \\
\hline Treet & Norway & 46 & & & $\begin{array}{l}\text { Glulam+ strong } \\
\text { concrete floors }\end{array}$ & Trusses \\
\hline $\begin{array}{l}\text { Timber bridge } \\
\text { (Fjell-leet) }\end{array}$ & Norway & - & & & Glulam & Trusses \\
\hline Hyperion & France & 57 & 30.6 & 19.1 & Glulam + CLT & Concrete Core \\
\hline Treed It & France & 36 & 47.4 & 18.6 & $\begin{array}{c}\text { Glulam + Tim- } \\
\text { ber Concrete } \\
\text { Slab }\end{array}$ & Concrete Core \\
\hline FlowerValley & Slovenia & 12.7 & 14.5 & 21.2 & CLT & Shear walls \\
\hline Kv Eken & Sweden & 24.4 & 27 & 19 & Glulam & Trusses \\
\hline Yoker & UK & 22 & 31 & 28 & CLT & $\begin{array}{l}\text { CLT Shear } \\
\text { walls }\end{array}$ \\
\hline
\end{tabular}

Table 1: Selected data about the building included measurements and main load-bearing system.

The buildings represent different modern timber building techniques and offer good examples of a variety of building types, providing a range in dynamic response for calibration and reliability in the modelling work. The buildings are dispersed across Europe providing a geographic spread. A bridge is included being an excellent example as to a similar type of glulam structure, including dowel connections, but with less non-structural elements. This will support research into the effect of connections versus non-structural elements.

The work in the project is divided into three interrelated main work-packages (WP2-4) and two supporting work-packages 1 and 5, see Figure 3. Work-packages 2 and 3 are experimentally based, to improve the understanding of the real behaviour of complete buildings measured insitu (WP3) and parts of the structural system (components, connections and sub-assemblies), known to influence the dynamic response, as measured in the lab (WP2).

Work-package 4 includes the modelling aspects of the project, with a starting point from using best engineering judgement information to develop models of the buildings to predict load levels and initial estimates of the buildings dynamic responses. The data from WP2 will create detailed FE-models of the connections and sub-assemblies simulating the measured behaviour. These models will be simplified and used for model calibration of the FE-model for 
the complete buildings, whilst also being calibrated against measurement data for the complete buildings.

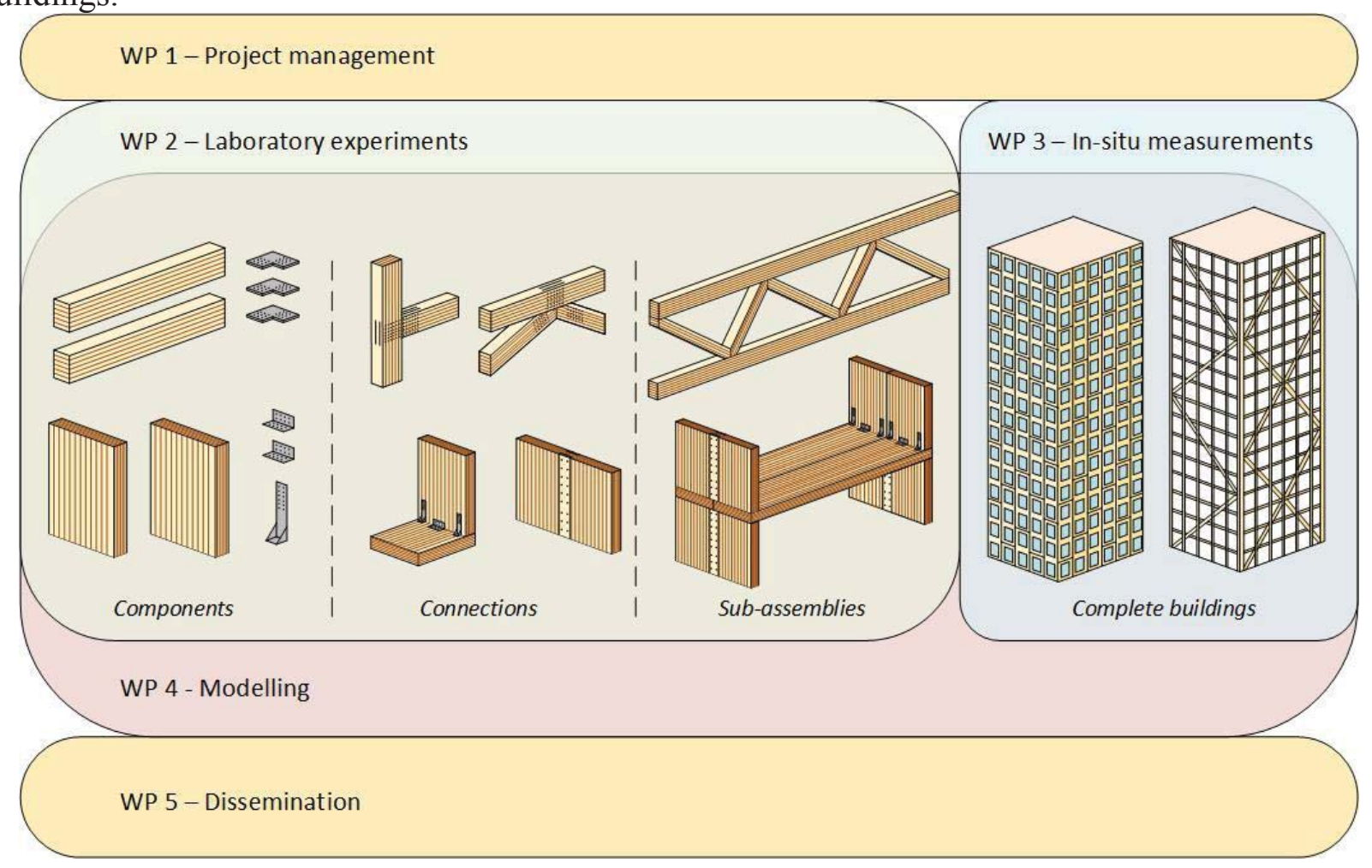

Figure 3: Project structure - WP2 - Laboratory experiments and WP3 - In-situ Measurements will run in parallel whilst WP4 - Modelling supports the measurement WPs and is calibrated with data from measurements. WP1 Project management and WP5 - Dissemination will run during the whole project time for support and exploitation of the results.

The project is on-going and so far, measurements using forced vibrations have been conducted on two buildings, Treed-It in Paris and Yoker in Glasgow. Preliminary results from the measurements and modelling of these two buildings will be presented in this paper as well as an overview of the measurement techniques and modelling techniques used.

\section{EXAMPLES OF BUILDINGS AND RESULTS}

\subsection{The Treed-It Building - structure}

Treed-It is a 12 story building with the first podium story in concrete and then 11 stories with a glulam structure. The building is stabilized against horizontal loads with an elevator shaft in concrete. The building is located in Champs-sur-Marne and is constructed by Vinci Engineering with Arbonis as the main contractor for the timber parts of the structure. The main part of the construction work has been done during 2019 with the timber structure being raised during July to October 2019. The building was finished July 2020. 


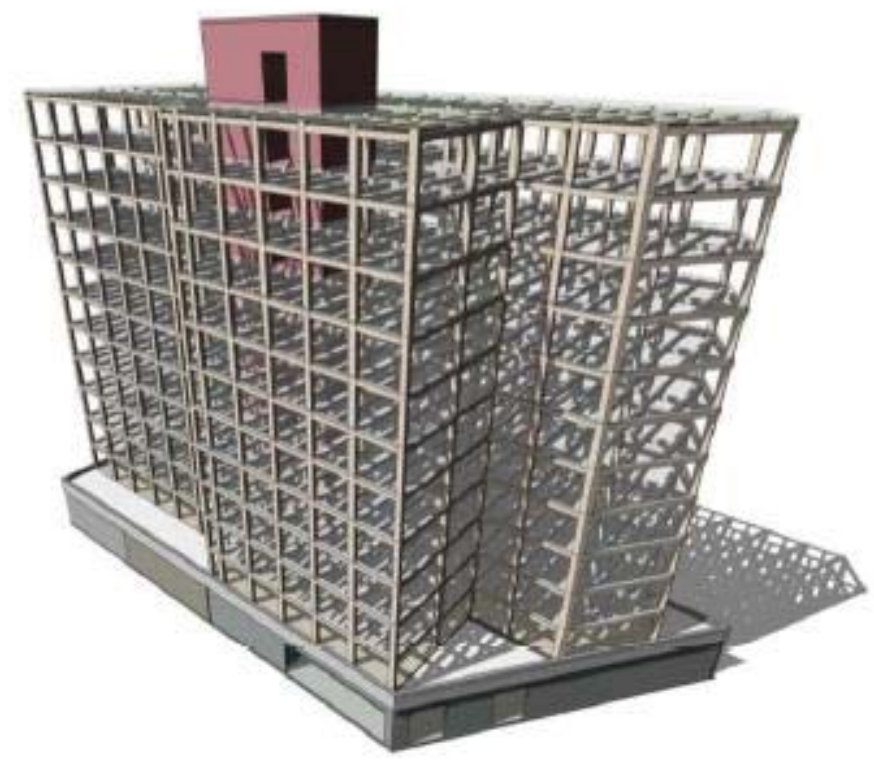

Figure 4: The structure of the Treed-It building with a concrete core and a glulam structure around it and mix timber-concrete floor slabs.

\subsection{Modelling of Treed-It}

An FE-model of the Treed-It building has been built using Ansys by CSTB. The structure is modelled using beams for the timber part and shells for the concrete and mix parts. As the building was not totally completed at the time of the dynamic measurements, the modelling takes into account the missing dead loads corresponding to inner partition that were not in place when natural frequencies have been measured. Oppositely, the stiffness of the structure was already the same as the final one. Cladding, that was already finished, is considered as bearing only load and no rigidity because façade is not contributing to the horizontal strength.

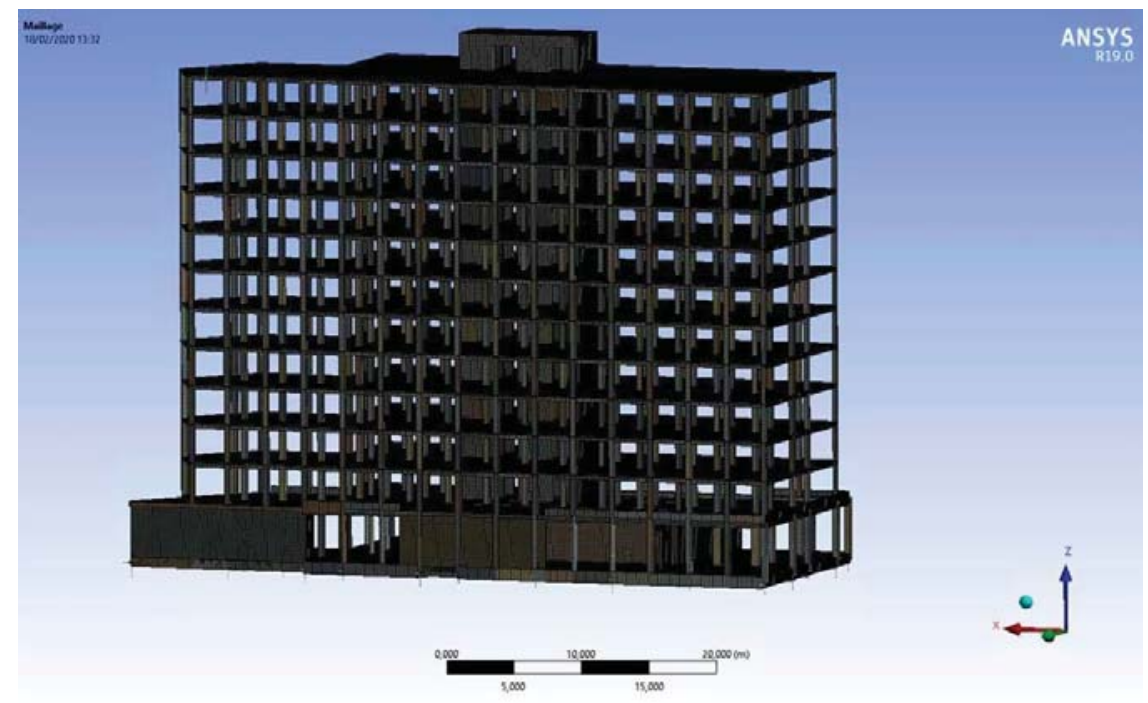

Figure 5: Ansys model of the Treed-It building by CSTB, using beam elements for the columns and beams and shells for the slabs and the concrete core. 


\section{B: Modale}

Déplacement total

Type: Déplacement total

Fréquence: $1,294 \mathrm{~Hz}$

Unité: $m$

10/12/201911:12

\begin{tabular}{|l}
$0,0010372 \mathrm{Max}$ \\
0,00092631 \\
0,00081541 \\
0,0007045 \\
0,0005936 \\
0,0004827 \\
0,0003718 \\
0,0002609 \\
0,00014999 \\
\hline
\end{tabular}

$3,9093 \mathrm{e}-5 \mathrm{Min}$

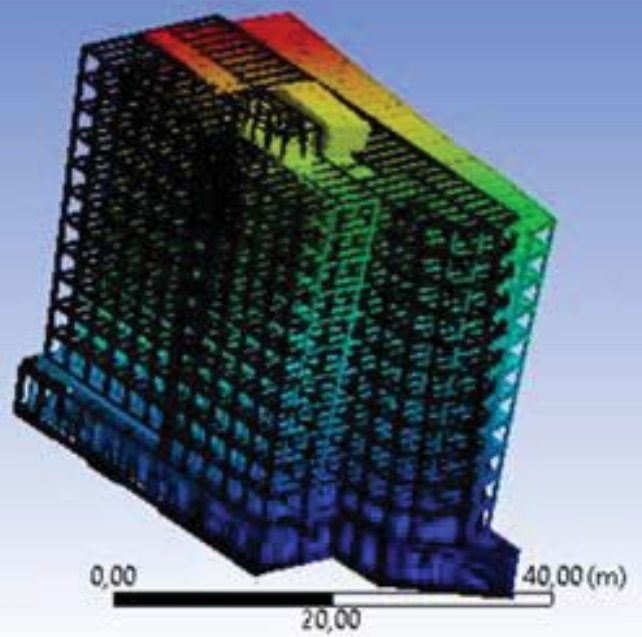

ANSYS

R19.0

B: Modale

Déplacement total 2

Type: Déplacement total

Fréquence: $1,5392 \mathrm{~Hz}$

Unité: $m$

10/12/201911:17

\begin{tabular}{|l}
0,0010877 Max \\
0,00098146 \\
0,00087524 \\
0,00076901 \\
0,00066278 \\
0,00055656 \\
0,00045033 \\
0,00034411 \\
0,00023788 \\
0,00013165 Min
\end{tabular}

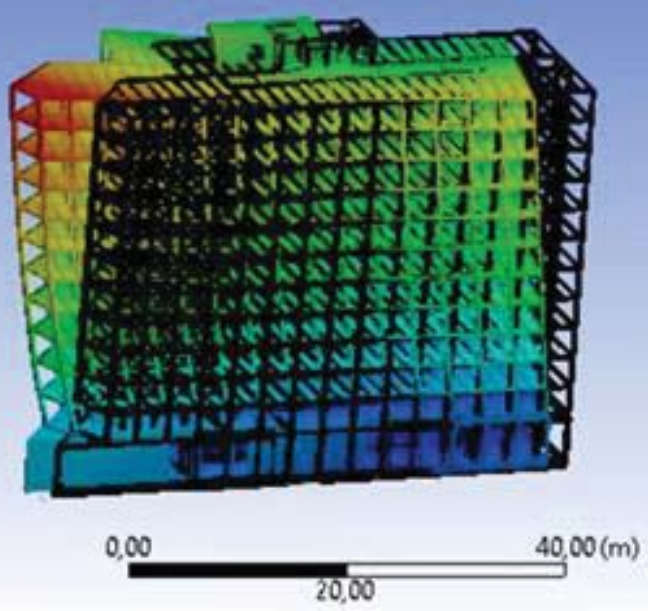

ANSYS

R19.0

B: Modale

Déplacement total 3

Type: Déplacement total

Frequence: $1,6979 \mathrm{~Hz}$

Unité: $m$

10/12/2019 11:13

\begin{tabular}{|l}
$0,0012292 \mathrm{Max}$ \\
0,0010941 \\
0,00095895 \\
0,00082381 \\
0,00068867 \\
0,00055353 \\
0,0004184 \\
0,00028326 \\
0,00014812 \\
$1,2983 \mathrm{e}-5$ Min
\end{tabular}

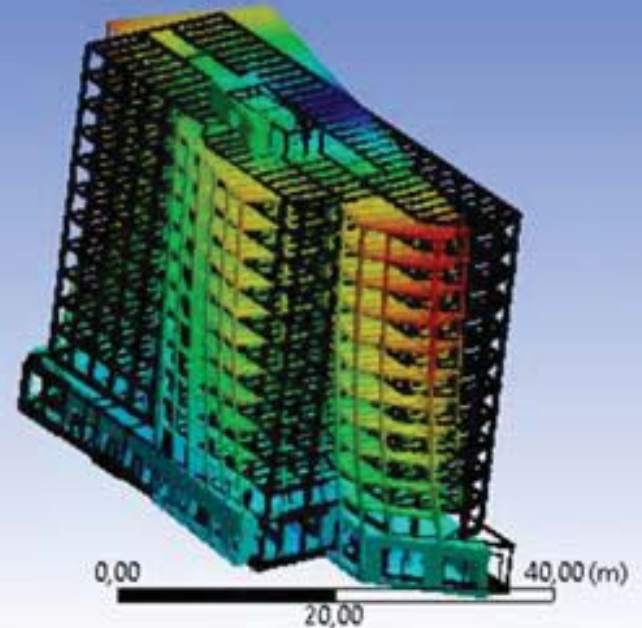

ANSYS

R19.0

Figure 6: Dynamic analysis of the Treed-It Building performed by CSTB before the real testing. 


\subsection{Testing of Treed-It}

The dynamic properties of the Treed-It Building was measured by CSTB using a horizontal mass shaker with a moving load of 500kg. The shaker was lifted in one piece to the top floor by a tower crane. With a stroke of $240 \mathrm{~mm}$ the sinusoidal force applied to the building was up to $8000 \mathrm{~N}$. This applied force increases with the square of the frequency, as it is an inertial exciter. A first measurement campaign was conducted in December 2019 without internal partition.
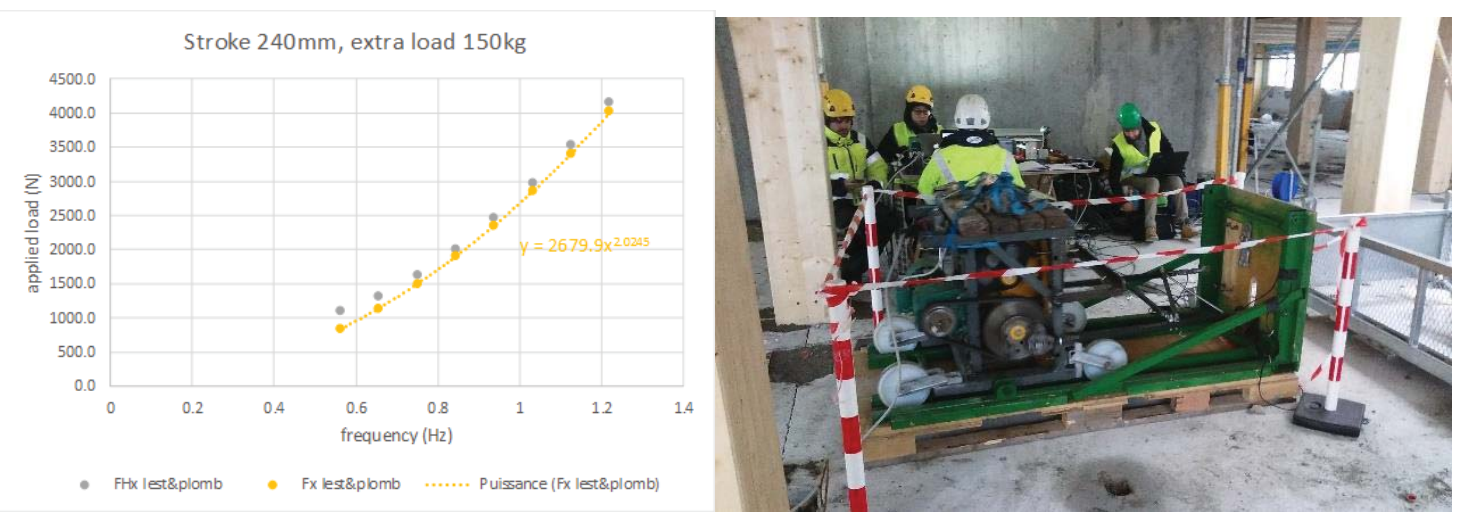

Figure 7: Horizontal force applied by the mass shaker for a given stroke (left) and shaker in operation on the Treed It Building (right)

Three locations of the shaker have been tested. Accelerometers were placed at three levels (11th, 7th and 2nd floor) to measure the amplitude of floor displacements, some displacement sensors (LVDTs) put between timber beam at the 7th level to measure the deformation of the structure. The preliminary analysis of the time domain signal show damping ratio close to $2 \%$ of critical, calculated from the decay of the acceleration signals. A more refined analysis shows damping is amplitude dependent. For large amplitudes $\left(0.05 \mathrm{~m} / \mathrm{s}^{2}\right.$ to $\left.0.1 \mathrm{~m} / \mathrm{s}^{2}\right)$ the structural damping ranges from $2.5 \%$ to $3.5 \%$ of critical, depending on which mode is excited. For low amplitudes (less than $0.01 \mathrm{~m} / \mathrm{s}^{2}$ ) the damping ratio drops down to $1 \%$ of critical or less.

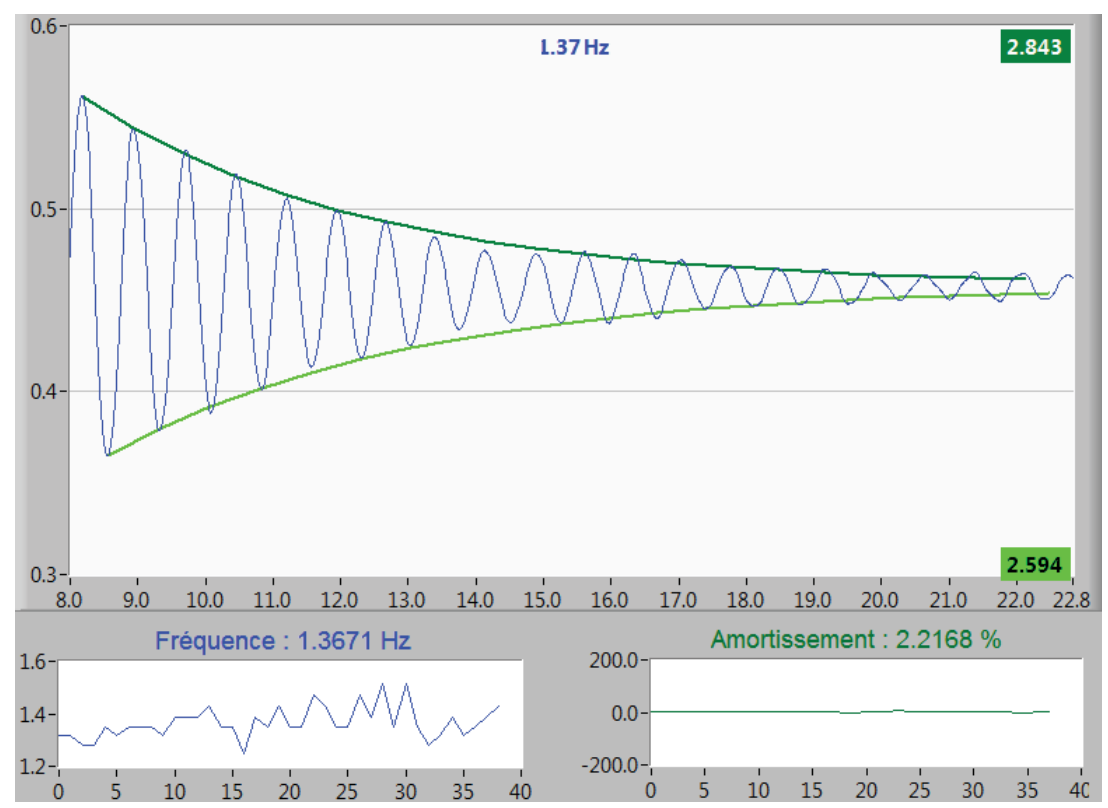

Figure 8: An example of decay of an accelerogram of shutdown test, amplitude in $\mathrm{m} / \mathrm{s}^{2}$ 
A second measurement campaign on Treed It was achieved in June 2020, with all internal partitions done. These partitions added mass and stiffness at the same time : the balance of both gives a slight increase of frequency for the first bending mode, a more marked decrease for the second bending mode and the torsion one.

\section{CONCLUSIONS}

The DynaTTB research program will provide valuable information concerning the FE modelling of high-rise timber buildings, to be used by designers for assessing the comfort of final users. The modeling of structural damping of such structures is one of the main input of this European research.

\section{FURTHER WORK}

A FE-model of the Yoker building, which is a 7 storey building in Glasgow designed by Smith and Wallwork Ltd, made using a CLT structure, has been modelled using Ansys by University of Ljubljana. The dynamic properties of the Yoker building was measured Feb 2020 by University of Exeter using horizontal shaker. The Hyperion building in Bordeaux was first tested in July 2020 and will be tested again when completed in March 2021. Data processing is under way.

An extensive measurement campaign in Scandinavia is planned at spring 2021.

\section{ACKNOWLEDGEMENT}

The research leading to these results has received funding from the ForestValue Research Programme which is a transnational research, development and innovation programme jointly funded by national funding organisations within the framework of the ERA-NET Cofund 'ForestValue - Innovating forest-based bioeconomy.

\section{REFERENCES}

[1] Malo, K.A., Abrahamsen, R.B. \& Bjertnaes, M.A., 2016. Some structural design issues of the 14-storey timber framed building "Treet" in Norway. European Journal of Wood and Wood Products, 74(3), pp.407-424.

[2] Brandner, R., Flatscher, G., Ringhofer, A., Schickhofer, G., Thiel, A. 2015. Cross laminated timber (CLT): overview and development. Holz als Roh- und Werkstoff 74(3).

[3] Feldmann, A., Huang, H., Chang, W., Harris, R., Dietsch, P., Gräfe, M., Hein, C. 2016. Dynamic properties of tall timber structures under wind-induced vibration. In WCTE 2016 - Word Conference on Timber Engineering. Vienna, Austria.

[4] Anon 2005. SS EN 1991-1-4:2005 Eurocode 1: Actions on structures - Part 1-4: General Actions - Wind actions, SIS (2002).

[5] Anon 2008. SS-ISO 10137:2008, Basis for Design of Structures-Serviceability of Buildings and Walkways against Vibration, ISO (2008). 
[6] Johansson, M. et al., 2016. Tall timber buildings - a preliminary study of wind- induced vibrations of a 22-storey building. In WCTE 2016 - Word Conference on Timber Engineering. Vienna, Austria.

[7] Reynolds, T., Casagrande, D. \& Tomasi, R., 2016. Comparison of multi-storey crosslaminated timber and timber frame buildings by in situ modal analysis. Construction and Building Materials, 102, pp.1009-1017.

[8] Fjeld Olsen, M., Hansen, O. 2016. Measuring vibrations and assessing dynamic properties of tall timber buildings, Master thesis NTNU, Trondheim Norway.

[9] Ewins, D. J. (2000). Modal Testing: Theory, Practice and Application. Research Studies Press.

[10] Magalhães F., Caetano E., Cunha A., Flamand O., Grillaud G., Ambient and free vibration tests of the Millau Viaduct: Evaluation of alternative processing strategies, Engineering Structures, Volume 45, December 2012, Pages 372-384.

[11] Zivanovic S, Pavic A, Reynolds P. (2007) Finite Element Modelling and Updating of a Lively Footbridge: The Complete Process, Journal of Sound and Vibration, volume 301, pages 126-145

[12] On site testing of the Treed-It building - CSTB report. 